\title{
LEXICON
}

\section{REFLEXIVE PERSONAL METADISCOURSE IN RESEARCH ARTICLES ON LANGUAGE LEARNING: A DISCOURSE ANALYSIS}

\author{
Lukas Nugroho Tjioe
}

\begin{abstract}
INTISARI
Penelitian ini bertujuan untuk mengidentifikasi fungsi-fungsi metawacana personal refleksif dalam artikel riset tentang pembelajaran bahasa. Data untuk riset ini diambil dari 17 artikel riset, yang mencapai jumlah 177,309 kata, yang dipublikasikan dalam Language Learning and Technology, sebuah jurnal mengenai pembelajaran dan teknologi bahasa. Secara keseluruhan, 66 penggunaan metawacana personal refleksif ditemukan menjalankan 16 fungsi yang berbeda. 93.94\% temuan dalam riset ini mengomentari wacana tertulis yang sedang berlangsung (Metateks), sementara $6.06 \%$ menjalankan interaksi antara penulis dan pembaca. Jumlah kemunculan metawacana personal refleksif, walaupun memiliki kegunaan yang beragam, yang kecil ini menunjukkan bahwa metawacana personal refleksif belum banyak menjadi pilihan dalam penulisan akademik.
\end{abstract}

Kata kunci: refleksif, personal, metawacana, metateks, interaksi, artikel riset.

\begin{abstract}
This research attempts to identify the functions of reflexive personal metadiscourse in research articles on language learning. Data for this research were taken from 17 research articles, totaling 177,309 words, published in Language Learning and Technology, an online refereed journal of language learning and technology. In total, 66 instances of reflexive personal metadiscourse were found serving 16 different functions. $93.94 \%$ of the instances commented on the on-going text, while $6.06 \%$ established interaction between the writer and the audience. The small number of occurrences of personal metadiscourse, though having various functionalities, has yet to gain considerable favor in academic writing.
\end{abstract}

Keywords: reflexive, personal, metadiscourse, metatext, interaction, research articles. 


\section{INTRODUCTION}

Metadiscourse is broadly defined as "text about text" (Adel 2006: 2), but more precise definitions of the notion metadiscourse is far more complicated than that. One trend in the research on metadiscourse includes the category of metadiscourse on any text elements virtually not related to the propositional content of the text. Vande Kopple's (1985, 1988) and Hyland's (1998)'s taxonomies, which have been adopted to numerous research into metadiscourse, for example, register instances such as according to $X, I$ agree, and it seems. This approach to metadiscourse is termed 'integrative' or 'narrow' approach (Adel 2006: 157). On the other hand, the 'non-integrative' approach (ibid.) (for example, Mauranen 1993) emphasizes language reflexivity to delimit metadiscourse. Instances like according to $X$ and it seems above do not count as metadiscourse under this approach since they do not reflexively refer to the on-going discourse. This strong emphasis on reflexivity consequently also results in the exclusion of personal representation from the category of metadiscourse. An example is the exclusion of rhetorical questions because that category is "concerned with the reader-writer relationship rather than directly with the text" (ibid. 180).

Putting the dispute aside, a research on metadiscourse has overall covered a broad range of topics. Not only L1 English as the main language of academic communication has been investigated. Numerous languages and L2 English have been called in contrastive rhetoric research concerning metadiscourse (for example, Mauranen 1993, 1993a; Vassileva 2000; Dahl 2004; Adel 2006; Pérez-Llantada 2007, 2010; Duszak \& Lewkowicz 2008). Many other researchers have also looked into metadiscourse in spoken discourses in various rhetorical conditions as well (for example, Schriffin 1980; Luukka 1994;
Godó Ágnes 2011; Adel 2010). More importantly, metadiscourse has been found to help the conveyance of information and comprehension on the part of the audience and language education in general (for example, Cheng \& Steffensen 1996; Camiciottoli 2003; Pérez \& Macia 2002; Amiryousefi \& Rasekh 2010; Massaabi 2014). Metadiscourse is also seen under the light of speech act theory (Beauvais: 1989) Furthermore, when personal metadiscourse is distinguished (for example, in Adel 2006, 2010), metadiscourse clearly represents part of academic identity and voice. In these and even wider dimensions, researchers into metadiscourse have been active in many parts of the world from Scandinavia, the rest of Europe, Asia, Australia, to the US (Adel \& Mauranen 2010: 5).

Aside from the above-mentioned two traditions, Adel (2006) proposes a model of reflexive metadiscourse, combining text reflexivity emphasized in the non-integrative approach but still takes into account the interactivity of the integrative approach. In this model, metadiscourse is defined as "reflexive linguistic expressions referring to the evolving discourse itself or its linguistic form, including references to the writerspeaker qua writer-speaker and the (imagined or actual) audience qua audience of the current discourse" (Adel 2010: 75). This 'middle-path' model seeks to delimit metadiscourse not too broad that the category does not become "ragbag of unrelated pragmatic signals" (Hyland 1998a: 648), but not too narrow so as to "restrict the concept of metadiscourse too severely" (Adel 2006: 180).

Developing on three of the functions of language by Jakobson (1998), namely the metalinguistic (text-oriented), expressive (addresser-oriented), and directive (addressee-oriented) functions, Adel has been able to elaborate clearly the mechanisms of the framework. The features of metadiscourse are enumerated 
(Adel 2006: 27-29). The first feature, 'explicitness', requires "the reference to the world of discourse be overtly stated" (ibid. 27). The second feature, "world of discourse', necessitates actions carried out by metadiscursive expressions to happen in on discourse level only, not in the real world. The feature 'current discourse' means that metadiscourse also needs to work only within the on-going discourse. Finally, 'writer qua writer' and 'reader qua reader' features limit personal metadiscourse to, in accordance with the previous features, explicitly refers to the writer and/or reader of the current text in their roles as the writer and/or reader. Adel (2010) has also developed specifically a taxonomy of function of reflexive personal metadiscourse comprising 23 functions. It is this model of metadiscourse that is adopted in the present study, although with a slight modification: Speech Act Labels is modified to Discourse Act Labels to avoid reflexive personal metadiscourse being seen less as a discourse-functional category. The same modification applies to Other Speech Act Labeling.

In the research on metadiscourse in general, however, research employing Adel's reflexive model of metadiscourse has not been many in spite of the detailed framework she has presented. In fact, some researchers feel indisposed to use Adel's reflexive metadiscourse in their research for several reasons. Salek (2004: 61), for example, sees the explicit references to the discourse participants made necessary in Adel's model as discouraging because of the traditional nature of academic writing of being impersonal. Using Adel's model, therefore, would only be able to capture a small number of units of analysis. Cao \& Hu (2014) prefers Hyland's (2005) model because its popularity among other research would enable them to compare their findings to those of others.

Adel's (2010) taxonomy metadiscourse function was used by Ebrahimi \& Ebrahimi (2012) in investigating metadiscourse in Iranian English newspaper. Unfortunately, the corpus was so small, consisting of not more than 2,000 words from only two news pieces, and Adel's framework did not seem to be accurately applied as the three findings visibly lacked the features of metadiscourse set up in the model. Pérez-Llantada (2010) adapted Adel's (2006) model of metadiscourse into her research. She investigated the use of metadiscourse in the introduction and discussion sections of research articles (hereinafter "RAs") in Spanish, RAs in English written by Spanish researchers, and native English

Table 1. Functions of Reflexive Personal Metadiscourse

\section{Metalinguistic comments}

REPAIRING refers to both self- and other-initiated suggestions or alterations which correct or cancel a preceding contribution.

REFORMULATING refers to the offering of an alternative term or expression not because the

preceding contribution was seen as erroneous (as in the case of REPAIRING), but because of the added value of expansion.

COMMENTING ON LINGUISTIC FORM/MEANING includes metalinguistic references to linguistic form, word choice and/or meaning.

CLARIFYING spells out the addresser's intentions in order to avoid misinterpretation.

MANAGING TERMINOLOGY involves giving definitions and providing terms or labels for phenomena that are talked about.

Discourse organization 
INTRODUCING TOPIC to open the topic

DELIMITING TOPIC to explicitly state how the topic is constrained

ADDING TO TOPIC to explicitly comment on the addition of a topic or subtopic

CONCLUDING TOPIC to close the topic

MARKING ASIDES to open or close a "topic sidetrack" or digression

ENUMERATING to show how specific parts of the discourse are ordered in relation to each

other.

ENDOPHORIC MARKING to point to a specific location in the discourse; it refers to cases in which it is not clear or relevant whether what is referred to occurs before or after the current point (unlike PREVIEWING and REVIEWING),

PREVIEWING points forward in the discourse

REVIEWING points backward in the discourse

CONTEXTUALISING to comment on (the conditions of) the situation of writing or speaking, and thus contains traces of the production of the discourse.

\section{Discourse act labels}

ARGUING to stress the action of arguing for or against an issue

EXEMPLIFYING used when explicitly introducing an example

OTHER DISCOURSE ACT LABELLING discourse acts which are not sufficiently frequent ... to have their own label

\section{References to the audience}

MANAGING COMPREHENSION/CHANNEL to ensure that the addresser and addressee(s) are "on the same page", to use a common metadiscursive metaphor

MANAGING AUDIENCE DISCIPLINE cases in which the audience is directly addressed and typically instructed to do something

ANTICIPATING THE AUDIENCE'S RESPONSE predicting the audience's reaction to what is said

MANAGING THE MESSAGE used to emphasize the core message in what is being conveyed IMAGINING SCENARIOS asks the audience to see something from a specific perspective, often in a vivid and engaging fashion.

ALIGNING PERSPECTIVES takes it for granted that the reader takes the writer's perspective.

The reader's agreement is presupposed. (Adel 2006: 61)

APPEALING TO THE READER attempts to influence the reader by emotional appeal. The writer persona conveys her attitude with the aim of correcting or entreating the reader.

research articles. However, she assigned impersonal metadiscursive expressions as well as the personal ones to the taxonomy of personal metadiscourse functions.

Answering to the lack of attention to Adel's model of metadiscourse and especially to the reflexive personal metadiscourse, the present research specifically studies the use of personal metadiscourse using Adel's (2006) model and (2010) taxonomy of functions of reflexive personal metadiscourse in 17 RAs of 177,309 words in total.

\section{METHOD}

The corpus of this research were constructed from first RAs available online of each of the last 17 issues of Journal of Language Learning and Technology (LLT) (http://llt.msu.edu/), a refereed journal of language education and technology (for the full list of the corpus article, see Appendix). A concordancing Software, AntConc, was used to find personal pronouns, their oblique forms, and nouns referring to the writer and the reader. NPs referring to the discourse participants were the starting points in determining the data. Parts of VPs that 
also refer to the on-going discourses were also included in the data. In cases where the reference to the discourse participants was in oblique forms of personal pronouns or nouns referring to the discourse participants, the superordinate linguistic forms they were constituents of and the relevant parts of those linguistic forms would be the data.

In determining the functions of the expressions delimited above, discourse analyses were performed, considering the context-dependency of metadiscourse (Mauranen 1993). The analyses considered scopes of varying length according to the case-specific needs, from the sentences in which the metadiscursive expressions appear to several sentences before and after the clauses. Analyses with

appropriate length of scopes were important in determining the functions of the expressions, which are the focus of the present study.

following

Example codification follows the LLT.[volume].[issue].[page] pattern:

\section{FINDINGS}

Table 2 displays the frequency and distribution of the functions of personal metadiscourse found on the 17 journal articles.

Table 2. The frequency and distribution of personal metadiscourse functions in language learning RAs.

\begin{tabular}{llcc}
\hline \multicolumn{1}{c}{ Functions } & $\begin{array}{c}\text { Raw } \\
\text { frequency }\end{array}$ & $\begin{array}{c}\text { Total } \\
\text { percentage }\end{array}$ \\
\hline Metalinguistic comments & 11 & $16.7 \%$ \\
\hline Repairing & 0 & $0.0 \%$ \\
Reformulating & 0 & $0.0 \%$ \\
Commenting on linguistic form/meaning & 3 & $4.5 \%$ \\
Clarifying & 2 & $3.03 \%$ \\
Managing terminology & 6 & $9.09 \%$ \\
\hline Discourse organization & 42 & $63.64 \%$ \\
\hline Introducing topic & 6 & $9.09 \%$ \\
Delimiting topic & 4 & $6.06 \%$ \\
Adding to topic & 0 & $0.0 \%$ \\
Concluding topic & 4 & $6.06 \%$ \\
Marking asides & 0 & $0.0 \%$ \\
Enumerating & 12 & $18.18 \%$ \\
Endophoric marking & 5 & $7.57 \%$ \\
Previewing & 5 & $7.57 \%$ \\
Reviewing & 5 & $7.57 \%$ \\
Contextualising & 1 & $1.52 \%$ \\
\hline Discourse act labels & 9 & $13.64 \%$ \\
\hline Arguing & 7 & $10.61 \%$ \\
Exemplifying & 1 & $1.52 \%$ \\
Other discourse act labeling & 1 & $1.52 \%$ \\
\hline Subtotal & 62 & $93.94 \%$ \\
\hline $\mathbf{Z}$ References to the audience & 4 & $6.06 \%$ \\
\hline
\end{tabular}




\begin{tabular}{llc}
\hline Managing comprehension/channel & 0 & $0.0 \%$ \\
Managing audience discipline & 0 & $0.0 \%$ \\
Anticipating the reader's response & 0 & $00 \%$ \\
Managing the message & 0 & $00 \%$ \\
Imagining scenarios & 1 & $1.52 \%$ \\
Aligning perspective & 2 & $3.03 \%$ \\
Appealing to the reader & 1 & $1.52 \%$ \\
\hline Subtotal & 4 & $60.6 \%$ \\
\hline Total & 66 & $100.0 \%$ \\
\hline
\end{tabular}

Metatext personal metadiscourse was found in 62 instances (93.94\%), compared to 4 instances $(6.06 \%)$ of the Audience Interaction personal metadiscourse. Discourse Organization is the category which is most pronounced in the Metatext group of functions and also in terms of the total occurrences of personal metadiscourse captured in the study in general (63.64\%). Enumerating and Arguing contribute the most for the dominance of Metatext type with 12 and 7 occurrences. Meanwhile, four functions Repairing, Reformulating, Adding to Topic, and Marking Asides - were not found in the RAs. Under the Audience Interaction category, only 3 functions were found in the present study, namely Imagining Scenarios (1.52\%), Aligning Perspective (3.03\%), and Advising $(1.52 \%)$, also with small numbers of occurrences. Only functions found in this study will be discussed in the following sections.

\section{Metalinguistic Comments}

\section{Commenting on Linguistic Form/Meaning \\ Commenting on Linguistic} Form/Meaning "includes metalinguistic references to linguistic form, word choice and/or meaning" (Adel 2010: 84). This function is found in three occurrences as shown below.
(1) We use pseudonyms for all participants and anonymized each institution which we have called 'Kita University' and 'Minami University'. (LLT.16.2.49)

(2) I borrow the term noticing event from Godfroid et al. (2010) since both eye gaze and stimulated recall data are indirect indicators of noticing and tell us little about the nature of cognitive processing that ensues from such an event. (LLT.16.3.62)

(3) I signify a noticing event with the symbol "+" and the absence of a noticing event with the symbol ". ".(LLT.16.3.62)

Example (1) informs of the use of pseudonyms for all of the participants of the study mentioned in the paper and of the anonymization of the participating institutions. It relates to the use of linguistic forms within the on-going discourse. In example (2), the author explicitly remarks that the term 'noticing event' is borrowed from another study. Meanwhile, example (3) comments on the use of the symbols "+" and "_. for specific phenomena investigated in the study. However, it is point to note whether cases like the example (3), using non-linguistic orthographic forms of "+" and "_.", should be counted in the function of Commenting on Linguistic Form/Meaning or not. 
The 'borrowing' practice of this function was also found in Adel (2010, 84): To put it in Fregean language, we can therefore say that "statue" is one mode of presentation of. The practice of borrowing might be performed to ensure that communication ensues with common understanding bridged by the use of linguistic forms by a third party. It also helps hint at the audience the knowledge level of the writer.

This function was not found in American, British, and Swedish learner English argumentative essays (Adel 2006). Perhaps, the lack of need for advanced terminology or a well-read persona may provide an answer to this difference.

\section{Managing Terminology}

This function encompasses giving definition and providing terms to be used in the on-going text. Managing Terminology was found more frequent than the other code-oriented Metatext functions in this study with 10 occurrences. It also featured significantly in numbers in Pérez-Llantada's (2010: 48) study, especially in introduction sections. This suggests that Managing Terminology is understandably an important function as it sets agreements between both parties of discourse participants in the use of the code in the on-going discourse, which in turn accommodates felicitous communication.

Two examples found in the present study are as follow.

(4) One corpus (the L2 or learner corpus) contained writing from L1 Chinese learners of L2 English, while the two other comprised L1 writing: one from academics (whom we term "expert" writers) and the other university students (who are similar in background to the L1 Chinese learners, aside from their first language). (LLT.14.2.31)

(5) Therefore, for the purpose of this study, we define blended language learning as the combination of CALL classrooms and face-to-face classrooms within a single physical environment. (LLT.16.2.49)

The examples show the two elements of the function Managing Terminology. In example (4), introduces a term - "expert" writers - is introduced for use in the paper. In example (5), the term 'blended language learning' is defined. It seems that in RAs, both aspects of the function Managing Terminology are familiar.

The function Managing Terminology was not recognized in full in student argumentative essays (Adel 2006), featuring only 'Defining', which covers only when a term is elaborated but not when a term is introduced for use in the text. Although the authors in the present study did not only offer their own terms but also borrow them from sources elsewhere, the absence of terminology offering by the students can be seen as a lack of authority by which the RA authors were enabled to do so. Possibilities the impersonal exercises of Managing Terminology, though, should not be dismissed.

Vassileva's (1998) study recorded the function Managing Terminology in academic writing with the use of the pronoun $I$. The present study found only co-occurrence of this function with the pronoun we. The pronoun we, though, did refer to the authors exclusively, and therefore the discrepancy can be safely regarded as caused merely by the difference of the number of authors. 


\section{Discourse Organization}

\section{Introducing Topic}

Introducing Topic appeared 6 times or $9.09 \%$ of the total instances of personal metadiscourse found in this study. Adel (2006: 66) asserts that "[e]xplicit proclamations of what the text is going to be about facilitates the processing of the subsequent text for the reader." Unsurprisingly, this function is commonly found in introduction sections in RAs (Pérez-Llantada 2010: 48) and in early paragraphs in argumentative essays (Adel 2006: 67). Especially in the latter's case, the position of this function seemed to be influenced by the essay structures, which were not partitioned with headings.

The present study on RAs, which are divided into sections with section headings, found that the topics being introduced were not only the general topics of the articles, but also topics of specific sections. Below is an example:

(6) Let us now turn to what is known about the way pitch is used by native and non-native speakers as they speak in public. (LLT.13.3.34)

Such announcements of the topic similarly took up positions in the beginning of sections the topics of which were being announced. Individual Introducing Topic of more specific parts serves similar purpose to what Cao \& Hu (2014: 18) term Topicalizers, which are "to shift between topics". Some examples of Topicalizers are with regard to, and turning to. Topicalizers are part of Hyland's (2010) Frame Markers.

\section{Delimiting Topic}

Delimiting Topic "explicitly state[s] how the topic is constrained" (Adel 2010: 85). Naturally, it follows that the topic has been previously stated before the function is employed. The four instances of Delimiting Topic found in the present study did come after elaborations of the general topics or themes. Two instances presented delimitation in line with the general topics, such as the following.

(7) There were two main developments in the 1980s and 1990s that linked the field of corpus linguistics to foreign language teaching research and pedagogy. ... In line with the present study, we concentrate on the second case, (that is, computer learner corpora), and their applications in the field of language teaching and learning. (LLT.17.2.37),

Meanwhile the other two are not in accordance with the general topics, indicated by however, as indicated below.

(8) Intonation has many functions in English, many of which are related to the interaction between speakers in dialogue. In this study, we focus, however, exclusively on intonational functions that are relevant for monologue. (LLT.13.3.33)

It should be noted that the use of however did not mean to ignore the general topics, but in these two cases it delimits the topics to specific parts to discuss. In this sense, the function Delimiting Topic is similar to Vassileva's (1998: 170) Focusing, which is to "narrow down goals, purposes, expectations concerning the outcome, etc., [...] concentrating the readers' attention on the specifics of what is to follow." Adel (2006: 67) also notices this function, but her instances delimit topics specifically internal to the discourse, while the 
instances here take the respective topics as delimited trends or activities outside the on-going discourse.

\section{Concluding Topic}

Concluding Topic closes the topic of the whole piece of writing or parts of it. In Hyland's (2010) study, concluding topics is a function of the 'Frame Markers' category. Concluding Topic appears in four expressions, two of which occur closely.

(9) The side-by-side tabulation of the queries and the accompanying comments allows us to track the development of Yilin's thinking. Just by examining the queries (left column), we can draw a tentative conclusion that these queries focus on lexical issues (that is, word choice) rather than on syntactic or morphological issues. (LLT.14.3.42)

(10) Then, by taking account of the writer's reflection (right column), we can confirm our conclusion with greater confidence. (LLT.14.3.42)

In this case, the two expressions were considered as separate instances of metadiscourse due to the additional premise taken into account in the second instance. These two expressions close the topic of a part of the on-going discourse.

On the other hand, the following example closes the RA.

(11) In the current study, through investigation of three groups of academic writing, it was found that there was a gap, in terms of the use of lexical bundles, between native expert academic writing and university student writing (native and non-native alike). We argue that, after careful selection and editing, the frequency-driven formulaic expressions found in native expert writing can be of great help to learner writers to achieve a more native-like style of academic writing, and should thus be integrated into $\mathrm{ESL} / \mathrm{EFL}$ curricula. (LLT.14.2.44)

In this instance, the topic concluded is that of the discourse, although the performative verb labels the speech act performed 'arguing'. Concerning this, considerations should be taken with the notion of metadiscourse as a discourse-functional category in mind. The function of the expression as Concluding Topic is evident from the previous statement which reviews the paper as a whole. The argument made from findings gathered in the study also seems to answer the research question which applies not only to specific parts of the discourse, but to the discourse as a whole. Finally, the location of the expression, which is in the last sentence of the body text further confirms its function as Concluding Topic expression.

Unlike examples of Concluding Topic featured in Adel (2010: 86) which only concludes whole essays, instances found here also conclude topics of parts of the on-going discourse. The function here goes in line with the function Introducing Topic, which does not only introduce topics general to the discourses, but also those specific to the parts of discourse.

Concluding function in personal metadiscourse does not seem to be used very frequently either in argumentative essays (Adel 2006: 79-80). She even asserts that this function is "rarely personalised in native-speaker material." Impersonal Concluding is instead found to be numerous in Pérez-Llantada's study (2010: 53), and in Hyland's (2010) Frame Markers, conclusions of topics can be 
expressed using impersonal expressions such as to conclude.

\section{Enumerating}

The function Enumerating was found to be the most common function in the 17 RAs with 12 occurrences. Enumerating comments on how parts of discourse are "ordered in relation to each other" (ibid.: 86). Two examples are as follow.

(12) In this article we first illustrate our current approach to training our students in corpus consultation. (LLT.14.1.29)

(13) We then present an evaluation of that approach through case studies of three students' use of a corpus and dictionary as reference resources while writing. (LLT.14.1.29)

The examples (11) and (12) occur in one sequence, and in performing their Enumerating function, they are correlated to one another. The examples show the order in which specific parts of the discourse are presented: Illustration of the approach to training the students in the study is 'first' presented, and is followed directly, as shown by the adverb 'then', by an evaluation of that approach. By taking into account the correlation displayed by these expressions, the function of these expressions could be quite clearly determined as Enumerating.

Example (14) contains two units. The relatively large number of occurrences has to do with this method of realization. There is also, however, an Enumerating instance which uses one verb only, as is shown below.

(14) We focus first on facility design (power in technologies), then materials design (power in authorship), and finally software design (power in licensing) (LLT.16.2.57)

In this case, because only one verb, 'focus on', is used, this instance only counts one unit. Because the mentioned parts of discussions are "ordered in relation to each other" (Adel 2010: 86), the function of this expression can clearly be determined as Enumerating.

\section{Endophoric Marking}

Endophoric Marking refers to specific parts of discourse without regards to whether the referred parts are before or after the marker, and the position of the referred parts are often not relevant, which differentiate it from Previewing or Reviewing (Adel 2010: 86). Previewing refers only to previous parts of discourse, while Reviewing only to parts of discourse ahead. In the RAs investigated, four out of five instances were found to refer to tables or parts of tables as shown in the two examples below.

(15) Detailed analysis on successful instances of negotiation of meaning initiated by NNSs is shown in Table 9 where we can see that "explanation" in the target language is the most frequently provided response by NSs. (LLT.15.1.56)

(16) In rows 3 and 4 we have evidence of the cognitive registration of the stimuli (Tomlin \& Villa, 1994 at some level (detection). (LLT.16.3.71)

One instance, shown below, referred to sub-sections

(17) At the beginning of each subsection, Structures or Discourse Functions, we begin by illustrating how the lexical bundles are 
categorized, structurally or functionally. (LLT.14.2.34)

Whichever the parts of discourse are referred, the locations of those parts of discourse relative to Endophoric Marking expressions are not clearly known or relevant.

\section{Previewing}

Previewing "points forward in the discourse" (Adel 2010: 86). The findings show that the part of discourse pointed in Previewing could be the unfolding part (shown in example (18)), part immediately coming after the Previewing (shown in example (19)), or part distant from the Previewing (shown in example (20)). Following are the examples.

(18) Our analyses in the following section are based on the recurrent word combinations retrieved and refined (for the full list, see Appendix). (LLT.14.2.34)

(19) I will argue in the next section that these cases present evidence of learners attending to the targeted items in the input at some level (beyond that required for simply reading it, in which case we would expect a heat map color of purple), but not at the level of noticing with awareness. (LLT.16.3.69)

(20) Later in this paper, we discuss how this policy affected power in the blended learning design process at Minami University. (LLT.16.2.50)

Each of the expressions shown in the example refers to parts of discourse ahead of their position. This characteristic enables identification of their Previewing function.

\section{Reviewing}

Reviewing, contrary to Previewing, "points backward in the discourse" (Adel 2010: 86). Five instances of Reviewing were found in this study, some of which had its previewed location clearly indicated as in example (21), vaguely indicated as in example (22), and not indicated at all as in example (23).

(21) In this paper, we have demonstrated that it is a variable that can effectively stimulate production as well. (LLT.13.3.45)

(22) I discussed earlier the multiple potentially confounding variables in interpreting recast research. (LLT.16.3.59)

(23) We argued that by investing in an online L2 identity our Russian learners demonstrated their digital wisdom in that they learned to accomplish a variety of social tasks beyond the scope of a simple exchange of information with a native speaking peer in a telecollaborative project. (LLT.17.1.83)

Perfective aspect is also often used in Reviewing, as in example (24). The use of the perfective aspect seemingly implies a kind of continuity that connects the previewed parts of discourse with the later parts of discourse, in which Previewing often occurs.

(24) We have presented qualitative and quantitative analyses of negotiation of meaning in chat transcripts involving two languages, English and Japanese. (LLT.15.1.59)

These instances all refer to previous parts of the discourse, which identifies them with the function of Reviewing. Reviewing finds its equivalent in Adel's (2006: 60), termed Reminding, 
which she found to be quite common as well in argumentative essays (ibid.: 79).

Enumerating, Endophoric Marking, Previewing, and Reviewing are equivalent to Hyland's (2010) Endophoric Markers, which he defines as "[making] additional material salient and available to the reader in recovering the writer's intentions by referring to other parts of the text" (ibid.: 128). Though not distinguishing between personal and impersonal kinds of metadiscourse, Hyland included in Endophoric Markers expressions such as noted above, see Fig, and in section 2 (ibid.). Moreover, Cao \& Hu (2014: 18) has made a finer distinction of Linear References (for example in this paper) and Non-linear References (for example as demonstrated in Excerpt 3). Endophoric Markers, including Adel's (2010) equivalents, have been found to be common in texts of various genres and languages - for example, British and undergraduate Malaysian academic essays (Chan \& Tan 2010: 130), Arabic and English RAs (Sultan 2011: 33), quantitative and qualitative RA methodology sections (Cao \& $\mathrm{Hu}$ 2014: 21).

\section{Contextualising}

Contextualising "exhibits traces of the production of the text" (Adel 2006: 64). In the RAs investigated here and native speaker argumentative essays (ibid.: 79), only a few instances of Contextualising were found, 1 instance in the former:

(25) The findings are discussed in terms of what we can learn about language learning and instructional design from TEILI. (LLT.18.1.71)

In this case, the 'trace of production' exhibited was the grounds for presentation of discussion. In argumentative essays, some instances include reasons of the topic (for example I have chosen this subject because I found it interesting to (Adel 2006: 65)) and resources restriction on the production of the text (for example $\underline{I \text { could }}$ go on much longer, but neither time nor space is unlimited and therefore I will return to the question why (ibid.)).

This function is found more common in spoken discourse. Luukka (1994: 80-81), labeling this function 'Contextual', found instances in spoken discourse exhibiting reasons for technical practices; for example I'll move this slide a little bit so that you can see better. Adel (2010: 88) found, among others, bases for discourse development (for example we're doing pretty well on time so let's) and also the bases for discourse halt (for example in the time we have remaining we can't um um, go on to great detail).

\section{Discourse Act Labels \\ 11. Arguing}

The function Arguing was found to be the most common personal metadiscourse function second only to Enumerating. It makes up $10.61 \%$ of the total personal metadiscourse occurrences with 7 instances. Some examples are as follow.

(26) I suggest that the six cases of incorrect despite the $\mathrm{SR}+$ score indicate that learners misreported what they noticed during the task. (LLT.16.3.68)

(27) We propose that L2 learners simultaneously construct in multiple analytical layers their intersubjective L2 identities: (LLT.17.1.71)

That Arguing exercises similar function to Hyland's Hedging can be seen in these two examples. By arguing, the authors pose the propositions as opinion, giving rooms for negotiation of meaning. Arguing is also especially common in discussion sections in RAs, though it is more often conveyed 
in impersonal manners (Pérez-Llantada 2010: 53).

Adel (2010: 92) views Arguing as important for academic writing in that "academic writers typically need to argue a point crucial to their "research story"". This assertion especially applies to the subject of the RAs investigated here, which is language learning. As a soft science, language learning relies on opinions of experts in the field, and Arguing is an option by which researchers visibly put forward their opinions.

\section{Exemplifying}

Exemplifying explicitly introduces an example. It was found in one instance.

(28) If we take, for instance, the use of definitely in sentence-initial position in extract 6 above, this adverbial position scores just one occurrence out of 292 matches in MICASE, which indicates that it is a very unusual sentence position. (LLT.13.1.51)

This instance employs the impersonal 'formulaic' expression for instance. With explicit reference to the discourse participants in 'If we take', the expression fulfills the function Exemplifying in Adel's (2010) taxonomy of personal metadiscourse functions. The small number of occurrences of this function, however, seems to suggest that impersonal Exemplifying, through expressions such as for example, without references to discourse participants, is more commonly employed in RAs. Pérez-Llantada (2010: $48,53)$ showed that including impersonal manners in the search of Exemplifying metadiscourse function would yield more findings.

\section{Other Discourse Act Labeling}

The category Other Discourse Act Labeling, an adaptation from Adel's Other
Speech Act Labeling (2010: 88), accommodates discourse functions of personal metadiscourse which do not occur frequently enough to have their own category. The single Other Discourse Act Labeling found in this study is Emphasizing, with the following example.

(29) However, we stress the fact that with a word processor, revision is an essential and necessary task, and one which can be performed at any point in the writing process; however, revision for many students simply involves "lastminute tinkering" as Hyland (1991, p. 26) describes. (LLT.17.2.49)

Emphasizing, based on this instance, foregrounds a piece of information that is to make up a premise of a larger argumentation. Other discourse acts recorded in Adel's (2010: 88) study are, for example, I am just mentioning it here as a possible alternative to and Based on this cross sectional analysis, I cannot answer any of the above hypotheses. Various discourse acts like these are essential in expanding, and probably also revising, the taxonomy of personal metadiscourse, which Adel herself asserts to be likely (ibid.: 82).

A use of the verb lexeme 'emphasize' is also found in Adel's (2010: 88) study: I want to emphasize, however, that this does not mean that family is in any way. It is classified as 'Other Speech Act Labelling' by virtue of the speech act it performs. Keeping the notion of metadiscourse as a functional category strict, this instance should be counted as Clarifying, because the speech act emphasizing visibly seeks to clear some possible misunderstanding, which therefore needs to be clarified. The function Clarifying can be seen from however, ... this does not mean that.

References to the Audience 


\section{Imagining Scenarios}

The function Imagining Scenarios "asks the audience to see something from a specific perspective, often in a vivid and engaging fashion" (Adel 2010: 89). It appears in one instance which proposes a negative scenario, as shown below.

(30) Thus, unless we are to discuss the pedagogical value of stimulated recalls, then it is best to proceed cautiously with our interpretations of any apparent differences in the DPT scores of the two measures and stress, rather, their similarity. (LLT.16.3.69)

It is different from the findings of Adel (2010: 90), which showed that scenarios imagined were used to support an argument (for example To use Hare's example, if I say that I ought to join the army). The small number of occurrences, along with its goal to delimit the scope of discourse act by imagining a scenario which is not happening, seems to suggest the difference of writing genre (RA and essay) to be the reason for this discrepancy. Another rationale that can be thought to serve as an explanation for the small number of the times this function is employed is that in the data-rich RAs, the authors can refer to the data, not to imagined scenarios.

\section{Aligning Perspective}

Aligning Perspective seeks to "have the reader take the writer's perspective", taking for granted "that the reader agrees with the writer" (Adel 2006: 76) Two instances of the function Aligning Perspective found in the study are as follow.

(31) Though the current study was not designed to specifically examine possible levels of awareness with respect to corrective feedback, the modest data presented here might serve as a springboard for future more in-depth investigations into this area. For example, we may interpret Table 8 in the following way: Assuming that the eye tracker was properly calibrated, rows 1 and $2(\mathrm{HM}=0)$ seem to show no evidence of detection since no significant eye gaze was registered over the targeted items. (LLT.16.3.71)

(32) We may say, then, that there seems to have been no registration of the stimuli at all (LLT.16.3.71)

The audiences' perspectives, in these two instances, are aligned with those of the authors through the pronoun we, which takes the audience into the authors' sides in viewing the proposition. In written discourse, it is quite evident that the communication operates one way from the writer's side. Therefore, the propositions and perspectives in RAs come from the authors. However, in the instances above, the audiences are included into the stances taken by the authors.

Aligning Perspective seems to be a strong rhetorical device in that the audience is assumed to agree with the writers on certain issues. The agreements can then be the bases for the authors to develop their argumentation in ways the audience would be more likely to follow. When put in the end of an argumentation, such as in the cases of the examples, the audience's agreement on the conclusion of the argument is assumed, and this may influence their decision on the truth value of the proposition.

\section{Appealing to the Reader}

The function Appealing to the Reader seems to influence the reader's attitude so that the arguments of the author can be accepted. This function appears in one instance in the RAs, as shown below. 
(33) Thus, unless we are to discuss the pedagogical value of stimulated recalls, then it is best to proceed cautiously with our interpretations of any apparent differences in the DPT scores of the two measures and stress, rather, their similarity. (LLT.16.3.69)

As can be seen, the instance shows that the function here advises caution for the audience in interpreting an aspect of the data. It seems that in this instance, the author seeks to deny a possible conclusion, and wants the reader not to accept it either. The author then appeals to the reader by advising caution to the said conclusion.

In Pérez-Llantada's study (2010: 57), this function is also used for the audience to consider an issue (The first consideration should be made regarding). Pérez-Llantada's example exhibits an instance of impersonal method for exercising the function, which was found more common than the personal one. A similar use of this function was found by Adel (2006: 78) in argumentative essays. One instance was But in order for the information to have full effect must You and I keep our minds open.

\section{CONCLUSION}

This research paper has been an attempt to study the functions of reflexive personal metadiscourse in research articles (RAs) on language education. Investigating 17 RAs from the journal Language Learning and Technology (LLT) http://llt.msu.edu/), an online refereed journal of language education and technology, it employs a slightly modified version of Adel's (2010) taxonomy of personal metadiscourse in academic discourses to capture the occurrences of and assign function labels to personal metadiscursive expressions. The taxonomy consists of two major types: Metatext text/code-oriented metadiscourse - and Audience Interaction - metadiscourse oriented on the audience of the discourse. The former covers 18 functions, while the latter 5. Two functions, adapted from Adel's (2006) taxonomy built on L1 and L2 English argumentative essays, were added on the basis of instances found in the RAs.

From a total of 177,309 words, the study has registered 68 expressions, or 38 occurrences per 100,000 words, which were found to comply with the features of reflexive metadiscourse proposed by Adel (2006): 'Explicitness', 'world of discourse', 'current discourse', 'writer qua writer', and 'reader qua reader'. Between the two types, Metatext metadiscourse seems to be favored by the RA authors. Metatext metadiscourse represents $93.94 \%$ (62 instances) of the total occurrences of metadiscourse, while Audience Interaction $6.06 \%$ (4 instances). Of the total instances of Metatext metadiscourse, the most commonly found function is Enumerating with 12 instances (18.18\%), most likely because of its necessary multiple occurrences in sequences. The second function with the most occurrences is Arguing with 7 instances $(10.61 \%)$. While Adel (2010) originally include only metadiscursive instances of the verb lexeme 'argue', this study includes other verb lexemes such as 'propose' and 'suggest', considering metadiscourse as a (discourse-) functional category (Adel 2006: 22-23). Metatext functions of which the occurrences were not recorded are Repairing, Reformulating, Adding to Topic, and Marking Asides. Their absence may be attributable to the written nature of the discourse which allows times for planning and revision. However, the function Adding to Topic is also found to be used in impersonal manners (PérezLlantada's 2010: 50 and Cao \& Hu 2014: 21).

Audience Interaction metadiscourse is found lacking in the present study. Only three of its subordinate functions were found in four instances: 
Imagining Scenarios (1.52\%), Aligning Perspective $(3.03 \%)$, Appealing to the Reader $(1.52 \%)$. The last two functions were additions adapted from Adel's (2006) taxonomy of metadiscourse. These additions positively answer Adel's (2010: 82) remark that the taxonomy is "likely to need further revision". Despite the notable rhetorical values of Audience Interaction metadiscourse (Adel 2006: 76), the small numbers of Audience Interaction metadiscourse may be attributed to the traditional notion about academic writing which necessitates it to be impersonal for the sake of objectivity (Sanderson 2008: 57).

These findings seem to suggest that reflexive personal metadiscourse has yet to find favors in academic writing of research articles. The above-mentioned traditional notion of impersonal representation in academic writing may find its traces in the small number of occurrences of reflexive personal metadiscourse: 66 in 177,309 words, or 37 in 100,000 words and the small number of Audience Interaction metadiscourse found $(6.06 \%)$. Although instances of Self Mention (Hyland 2010: 129) are frequently used in the RAs, they mainly rhetorically fulfill the function of guidance, one of "the two main rhetorical functions of metadiscourse" (Adel 2006: 43), the other being interaction. That the function interaction, which engages both the addresser and addressee in a discourse, has yet to be adequately satisfied indicates that personal representation in academic writing has not been fully achieved. Another point to note from the findings of the present study and other relevant studies (for example, Pérez-Llantada's 2010 and $\mathrm{Cao} \& \mathrm{Hu} 2014)$ is that authors, in performing the listed functions of metadiscourse, seem to favor impersonal methods. In this study, comparisons of a significant number of the functions with findings of other research (Adel 2006, Adel 2010, Hyland 2010, Pérez-Llantada's 2010, and Cao \& Hu 2014) reveal more frequencies of impersonal metadiscourse performing the same functions.

This study is limited in several aspects, on which further research could improve. First, the failure to capture a significant number of functions other studies on reflexive metadiscourse (Adel 2006, Adel 2010, and Pérez-Llantada's 2010) have been able to find may be attributed to the small number of RAs in the corpus. Adel (2010), for example, investigated up to 130 essays totaling more than 400,000 words, compared to the present study's relatively small corpus of 17 articles of 177,309 words only. Further research with larger corpus sizes should yield inductively stronger results than those of the present study.

The present study also covers one journal which acts as the source of the 17 articles. As Sanderson (2008: 60) suggests, the representativeness of a sample relies on the inclusion of variables in the population. By including only one journal, chances are the present study misses several of those variables, or if such variables have been recorded, the size may need expansion. This being said, generalizations from the results of this study should be carefully made, taking into account the small size of the corpus. Further research paying special attentions to aspects of writing surely would uncover more diverse findings.

Furthermore, this study only considers the functions of reflexive personal metadiscourse. Function seems to be the most important aspect of metadiscourse, which is a discourse functional category, but investigation inclusive of form may also produce a more fruitful results.

Lastly, despite its limitations, factors of the study, such as construction of the corpus, were not done without any consideration. Having already captured most of the functions, and even added two 
functions, the study should be able to introduce and to at least hint at the tendency of the use of reflexive personal metadiscourse in RAs, especially those on language learning. The subject, language learning, is also hoped to present a writing convention, including the use of reflexive personal metadiscourse, which is effective for communication and conveyance of information. These elements have been considered to suffice for the purpose and scope of the present study.

\section{REFERENCES}

Adel, A. \& Mauranen, A. 2010.

"Metadiscourse: Diverse and Divided Perspectives" in Nordic Journal of English Studies, 9(2), 111.

Adel, A. 2006. Metadiscourse in L1 and L2 English. Amsterdam: John Benjamins

Adel, A. 2010. "Just to give you kind of a map of where we are going: A Taxonomy of Metadiscourse in Spoken and Written Academic English" in Nordic Journal of English Studies, 9(2), 69-97.

Amiryousefi, M. \& Rasekh. A. E. 2010. "Metadiscourse: Definitions, Issues and Its Implications for English Teachers" in English Language Teaching, 3(4),159-167.

Beauvais, P. J. 1989. "A Speech Act Theory of Metadiscourse" in Written Communication, 6(1), 1130

Camiciottoli, B. C. 2003. "Metadiscourse and ESP reading comprehension: An exploratory study" in Reading in a Foreign Language, 15(1), 2844.
Cao, F. \& Hu, G. 2014. "Interactive metadiscourse in research articles: A comparative study of paradigmatic and disciplinary influences" Journal of Pragmatics, $66,15-31$.

Cheng, X. \& Steffensen, M. S. 1996. "Metadiscourse: A Technique for Improving Student Writing" in Research in the Teaching of English, 30(2), 149-181.

Dahl, T. 2004. "Textual metadiscourse in research articles: A marker of national culture or of academic discipline?" in Journal of Pragmatics, 36, 1807-1825.

Duszak, A. \& Lewkowicz, J. 2008. "Publishing Academic Texts in English: A Polish Perspective" in Journal of English for Academic Purposes, 7(2), 108-120.

Ebrahimi, S. J. \& Ebrahimi, S. F. 2012. "Audience Interaction in Iranian English Newspaper" in Advances in English Linguistics, 1(4), 91-94.

Godó Ágnes, M. 2011. “Are you with me? A Metadiscursive Analysis of Interactive Strategies in College Students' Course Presentations" in International Journal of English Studies, 2(1), 55-78.

Hyland, K. 1998. "Persuasion and Context: The Pragmatics of Academic Discourse" in Journal of Pragmatics, 30, 437-455.

Hyland, K. 1998a. "Exploring corporate rhetoric: Metadiscourse in the CEO's letter" in Journal of Business Communication, 35(2), 224-245.

Hyland, K. 2005. Metadiscourse: Exploring Interaction in Writing. London: Continuum. 
Jakobson, R. 1998. On Language: Roman Jakobson, eds. L. R. Waugh \& M.Monville-Burston. Cambridge, MA and London: Harvard University Press.

Luukka, M. 1994. "Metadiscourse in Academic Texts" in eds. B. L. Gunnarsson, P. Linell, \& B. Nordberg, Text and Talk in Professional Contexts. Selected Papers from the International Conference "Discourse and the Professions, " Uppsala, 26-29 August, 1992." Uppsala: ASLA, The Swedish Association of Applied Linguistics.

Massaabi, A. 2014. "Metadiscourse and Reading Research Articles RA in English by Tunisian Geography Faculty" in Procedia - Social and Behavioral Sciences, 98, 1110 1118.

Mauranen, A. 1993. Cultural Differences in Academic Rhetoric: A Textlinguistic Study. Frankfurt am Main: Peter Lang.

Mauranen, A. 1993a. "Contrastive ESP rhetoric: Metatext in FinnishEnglish economics texts" in English for Specific Purposes, 12, 3-22.

Pérez, M. A. \& Maciá, E. A. 2002. "Metadiscourse in lecture comprehension: Does it really help foreign language learners?" in ATLANTIS, XXIV(2), 3-21.

Pérez-Llantada, C. 2007. "Native and Non-native English Scholars Publishing Research Internationally: a Small-scale Study on Authorial Invisibility" in Journal of Applied Linguistics, 4(2), 217-238.

Pérez-Llantada, C. 2010. "The Discourse Functions of Metadiscourse in
Published Academic Writing: Issues of Culture and Language" in Nordic Journal of English Studies, 9(2), 41-68.

Schiffrin, D. 1980. "Metatalk: Organizational and Evaluative Brackets in Discourse" in Sociological Inquiry: Language and Social Interaction, 50, 199236.

Salek, M. 2004. “A Diagram of Interactive and Interactional Markers in Different Parts of English Research Articles" in Journal of Language Sciences and Linguistics, 2(3), 5566.

Vande Kopple, W. J. 1985. "Some Exploratory Discourse on Metadiscourse" in College Composition and Communication, 26, 82-93.

Vande Kopple, W. J. 1988.

"Metadiscourse and the Recall of Modality Markers" in Visible Language, XXII, 233-272.

Vassileva, I. 2000. Who is the Author? A Contrastive Analysis of Authorial Presence in English, German, French, Russian and Bulgarian Academic Discourse. Sankt Augustin: Asgard Verlag.

\section{APPENDIX - LIST OF CORPUS ARTICLES}

Bower, J. \& Kawaguchi, S. 2011. "Negotiation of Meaning and Corrective Feedback in Japanese/English eTandem" in Language Learning \& Technology, 15(1), 41-71. Retrieved from http://lt.msu.edu/issues/february20 
11/bowerkawaguchi.pdf on 4 June 2014 at 1:47 p.m. WIB.

Chen, J. J. \& Yang, S. C. 2014. "Fostering Foreign Language Learning through Technology-Enhanced Intercultural Projects" in Language Learning \& Technology, 18(1), 5775. Retrieved from http://llt.msu.edu/issues/february20 14/chenyang.pdf on 4 June 2014 at 1:41 p.m.

Chen, Y. \& Baker, P. 2010. "Lexical Bundles in L1 And L2 Academic Writing" in Language Learning \& Technology, 14(2), 30-49.

Retrieved from http://lit.msu.edu/vol14num2/chen baker.pdf on 4 June 2014 at 1:49 p.m.

Chik, A. 2014. "Digital Gaming and Language Learning: Autonomy and Community" in Language Learning \& Technology, 18(2), 85100. Retrieved from http://ltt.msu.edu/issues/june2014/c hik.pdf on 4 June 2014 at 1:43 p.m.

Collentine, K. 2011. Learner Autonomy in a Task-Based 3D World and Production" in Language Learning \& Technology, 15(3), 50-67. Retrieved from http://lt.msu.edu/issues/october201 1/collentine.pdf on 4 June 2014 at 1:46 p.m.

Cross, J. 2011. Comprehending News Videotexts: The Influence of the Visual Content" in Language Learning \& Technology, 15(2), 4468. Retrieved from http://llt.msu.edu/issues/june2011/c ross.pdf on 4 June 2014 at 1:47 p.m.

Hincks, R. \& Edlund, J. 2009. Promoting Increased Pitch Variation in Oral Presentations with Transient Visual Feedback" in Language Learning \& Technology, 13(3), 32-50. Retrieved from http://llt.msu.edu/vol13num3/hinck sedlund.pdf on 4 June 2014 at 1:50 p.m.

Hinkelman, D. \& Gruba, P. 2012. Power within Blended Language Learning Programs in Japan" in Language Learning \& Technology, 16(2), 4664. Retrieved from http://llt.msu.edu/issues/june2012/h inkelmangruba.pdf on 4 June 2014 at 1:46 p.m.

Kennedy, C. \& Miceli, T. 2010. CorpusAssisted Creative Writing: Introducing Intermediate Italian Learners to a Corpus as a Reference Resource" in Language Learning \& Technology, 14(1), 2844. Retrieved from http://ltt.msu.edu/vol14num1/kenn edymiceli.pdf on 4 June 2014 at 1:50 p.m.

Kim, D., Rueckert, D., Kim, D., \& Seo, D. 2013. Students' Perceptions and Experiences of Mobile Learning" in Language Learning \& Technology, 17(3), 52-73. Retrieved from http://llt.msu.edu/issues/october201 3/kimetal.pdf on 4 June 2014 at 1:42 p.m. WIB. 
Klimanova, L. \& Dembovskaya, S. 2013.

L2 Identity, Discourse, and Social Networking In Russian" in Language Learning \& Technology, 17(1), 69-88. Retrieved from http://llt.msu.edu/issues/february20 13/klimanovadembovskaya.pdf on 4 June 2014 at 1:44 p.m.

MacDonald, P., Garcia Carbonell, A. \& Carot-Sierra, J. M. 2013. Computer Learner Corpora: Analysing Interlanguage Errors in Synchronous and Asynchronous Communication" in Language Learning \& Technology, 17(2), 3656. Retrieved from http://llt.msu.edu/issues/june2013/ macdonaldetal.pdf on 4 June 2014 at 1:43 p.m.

Motohashi-Saigo, M. \& Hardison, D. M. 2009. Acquisition of L2 Japanese Geminates: Training with Waveform Displays" in Language Learning \& Technology, 13(2), 2947. Retrieved from http://ltt.msu.edu/vol13num2/moto .pdf on 4 June 2014 at 1:46 p.m.. hashisaigohardison.pdf on 4 June 2014 at 1:50 p.m.

Park, K. \& Kinginger, C. 2010.

Writing/Thinking in Real Time: Digital Video and Corpus Query Analysis" in Language Learning \& Technology, 14(3), 31-50.

Retrieved from http://llt.msu.edu/vol14num3/parkk inginger.pdf on 4 June 2014 at 1:49 p.m.

Pérez-Llantada, C. 2009. Textual, Genre and Social Features of Spoken Grammar: A Corpus-Based Approach" in Language Learning \& Technology, 13(1), 40-58.

Retrieved from http://llt.msu.edu/vol13num1/perez llantada.pdf on 4 June 2014 at 1:50 p.m.

Smith, B. 2012. Eye Tracking as a Measure of Noticing: A Study of Explicit Recasts in SCMC" in Language Learning \& Technology, 16(3), 53-81. Retrieved from http://llt.msu.edu/issues/october201 2/smith 